\title{
Impact of International Relations in Trade \& Development from Bangladesh Perspective
}

\author{
Md. Amir Hossain \\ Senior Lecturer, Department of English, IBAIS University \\ Uttara, Dhaka-1230, Bangladesh.
}

OScholedge International Journal of Multidisciplinary \& Allied Studies (ISSN 2394-336X), Vol.02, Issue 12 (2015) pp29-42.

Published by: Scholedge R\&D Center [www.theSCHOLEDGE.org] [Email: sijmas@scholedge.org]

\begin{abstract}
The aim of this submission is focus on the elaborate discussion of international relation to make Bangladesh hold a good relation with the other countries of the world. Here, I have analyzed also trade, development and the concept of Thomas concerning development. It attempts to look at international relation with global economic trade, and development. Here my plan is to draw a new light on recommendation and the significance of my paper.
\end{abstract}

Keywords: Development, globalization, international relation, and trade.

\section{Introduction}

This paper shows the definition of international relation, trade, development, and some aspects of development. It also attempts to look at international relation and globalization, international relation \& economic trade and development from Bangladesh perspective. Here, I have briefly tried to shed a new light on the recommendations and the significance of the paper to create awareness of the people of Bangladesh regarding the global trade and development.

\section{International Relation}

International relations attempts to explain the interactions of states in the global interstate system and it also attempts to explain the interactions of others whose behavior originates within one country and is targeted toward members of other countries. In short, the study of international relation is an attempt to explain behavior that occurs across the boundaries 
of states, the broader relationships of which such behavior is a part, and the institutions including-private, state, non-governmental, and inter-governmental that oversee those interactions. Explanations of that behavior may be sought at any level of human aggregation. Some look to psychological and social-psychological understandings of why foreign policymakers act as they do. Others investigate institutional processes and politics as factors contributing to the externally directed goals and behavior of states. Alternatively, explanations may be found in the relationships between and among the participants (balance of power), in the intergovernmental arrangements among states (collective security), in the activities of multinational corporations (the distribution of wealth), or in the distribution of power and control in the world as a single system.

International Relations (IR) is the study of relationships among countries, the roles of sovereign states, inter-governmental organizations (IGO), international non-governmental organizations (INGO), non-governmental organizations (NGO), and multinational corporations (MNC). International relations is an academic and a public policy field, and so can be positive and normative, because it analyzes and formulates the foreign policy of a given state. As political activity, international relation dates from the time of the Greek historian Thucydides (ca. 460-395 BC), and, in the early 20th century, became a discrete academic field within political science. However, international relations is an interdisciplinary field of study.

Besides political science, the field of international relation draws intellectual materials in the fields technology and engineering, economics, history, and international law, philosophy, geography, and social work, sociology, anthropology, and criminology, psychology and gender studies, cultural studies and cult-urology. The scope of international relation comprehends globalization, state sovereignty, and international security, ecological sustainability, nuclear proliferation, and nationalism, economic development and global finance, terrorism and organized crime, human security, foreign interventionism, and human rights (Sutch, \&Juanita, 2007). 


\section{Trade}

Trade involves the transfer of the ownership of goods or services from one person or entity to another in exchange for other goods or services or for money. Possible synonyms of "trade" include "commerce" and "financial transaction." Types of trade include barter. A network that allows trade is called a market.

Trade exists due to the specialization and division of labor, in which most people concentrate on a small aspect of production, trading for other products. Trade exists between regions because different regions may have a comparative advantage in the production of some tradable commodity, or because different regions' size may encourage mass production. As such, trade at market prices between locations can benefit both locations.

Moreover, international trade is the exchange of capital, goods, and services across international borders or territories. In most countries, such trade represents a significant share of gross domestic product(GDP). While international trade has been present throughout much of history, its economic, social, and political importance has been on the rise in the 20th and 21st century. It is the presupposition of international trade that a sufficient level of geopolitical peace and stability are prevailing in order to allow for the peaceful exchange of trade and commerce to take place between nations.

Global trade gives consumers and countries the opportunity to be exposed to new markets and products. Almost every kind of product can be found on the international market: food, clothes, spare parts, oil, jewelry, wine, stocks, currencies and water. Services are also traded: tourism, banking, consulting and transportation. A product that is sold to the global market is an export, and a product that is bought from the global market is an import. Imports and exports are accounted for in a country's current account in the balance of payments.

Industrialization, advanced technology, including transportation, globalization, multinational corporations, and outsourcing are all having a major impact on the international trade system. Increasing international trade is crucial to the continuance of globalization. Without 
international trade, nations would be limited to the goods and services produced within their own borders. International trade is, in principle, not different from domestic trade as the motivation and the behavior of parties involved in a trade do not change fundamentally regardless of whether trade is across a border or not. The main difference is that international trade is, typically, more costly than domestic trade. The reason is that a border, typically, imposes additional costs such as tariffs, time costs due to border delays and costs associated with country differences such as language, the legal system or culture.

Another difference between domestic and international trade is that factors of production such as capital and labor are, typically, more mobile within a country than across countries. Thus international trade is mostly restricted to trade in goods and services, and only to a lesser extent to trade in capital, labor or other factors of production. Trade in goods and services can serve as a substitute for trade in factors of production. Instead of importing a factor of production, a country can import goods that make intensive use of that factor of production and thus embody it. An example is the import of labor-intensive goods by the United States from China. Instead of importing Chinese labor, the United States imports goods that were produced with Chinese labor. One report in 2010 suggested that international trade was increased when a country hosted a network of immigrants, but the trade effect was weakened when the immigrants became assimilated into their new country.

International trade is also a branch of economics, which, together with international finance, forms the larger branch called international economics. Trading is a value-added function: it is the economic process by which a product finds its market, in which specific risks are to be borne by the trader (Sen, 2005).

\section{Development}

The word 'development' is open to a great deal of controversy. To many, it can appear patronizing, especially when distinguishing between countries that are developed and those that are described as 'developing' or 'undeveloped'. One way that development is often measured in terms of changes in gross national product (GNP) per capita and comparative GNPs between countries. A country is said to be developing if its GNP is increasing. If the gap 
between its GNP and those of the so-called 'developed' countries is decreasing, the country is said to be moving

from being a less developed country to being a highly developed country.

On these terms, the newly industrialist countries (NICS) such as Singapore, South Korea, Taiwan, and Hong Kong are sometimes said to be rapidly reaching, and in some cases surpassing, Western standards of development. However, there are many problems with measuring development purely in terms of GNP per capita. Is the country as a whole really developing if the wealth disparity in the country is increasing, despite increases in aggregate GNP per capita? While the richest in the society may be getting substantially richer, the majority of the population may see no change in their living standards. Similarly, can a country be said to be developing if economic growth is achieved at a cost to future generations in terms of using up of undeniable resources and the pollution of air, land, and water? For example, the economic growth of many countries in the former Eastern bloc in the post-1945 period was achieved to a large extent with little care concerning the environment.

Another problem with the economic growth concept of development is that it ignores political liberties and the type of government that is presiding over the development. Many of the newly industrialist countries have had authoritarian governments during their period of growth. Can a country be said to be developing if its citizens are politically oppressed and have basic human rights denied, such as freedom of speech? The growth seen in the Chinese rush for industrialization in the 1950 s and 1960 s was at the expense of the welfare of the population who suffered widespread famine and terrible living condition.

Thus simply looking at GNP per capita is not an adequate way of measuring development. Economic growth may be one factor that constitutes development, but development does not simply involve economic growth and not all economic growth can be classed as development. Politically, the term 'development' has often been used to imply a move towards western systems of economy and government, or towards a western style of living. But some observers claim that it can be very patronizing to assume that westernization is the only path to development. 
Perhaps a better way to measure development is in terms of satisfaction of basic needs of all members of the society. Consequently, the provision of shelter, food, clean water, health and medicine, access to education, and other important elements that goes to make up an acceptable standard of living. If a country moves to provide these things, then it can be said to have developed. On this basis, many of the African countries can be seen as underdeveloped to provide these essentials. One way of measuring development is the provision of basic needs by looking at the number of people living at or below the poverty line. This is useful in looking at changes within a country over time, as it is an indication of the distribution of wealth in a particular country. However, as a country becomes richer, the standard by which poverty is measured will increase. What constitutes poverty in Germany is very different to what constitutes poverty in Sudan.

Actually, development does not simply involve economic growth. One needs to examine the cost of such growth, the distribution of any increase in wealth, and the provision of essentials to achieve a decent standard of life to all. Human development is a process of enlarging people's choices. The most critical of these wide-ranging choices are to live a long and healthy life, to be educated, and to have access to resources needed for a decent standard of living. Development enables people to have these choices. The process of development should create a conducive environment for people, individually and collectively, to develop their full potential and to have a reasonable chance of leading productive and creative lives in accordance with their needs and interests.

Underdevelopment is obviously extensive. Depending on where we draw the line between developed and underdeveloped, the underdeveloped world makes up about three-quarters of the world's population. We should also take note of the persistence of underdevelopment. The membership of the exclusive club of rich countries has not changed much between 1900 and the present. Why should we, in the advanced industrialized states, be concerned regarding the prospects for the development of the rest of the world? First are the obvious humanitarian reasons - can we really enjoy our wealth when poverty is the normal condition of most of the world? Secondly, our economic self-interest calls for rapid 
development of the rest of the world: our export markets will thereby grow; and there will no longer be the lure of low wages to siphon away our jobs. Thirdly, a more developed world is likely to be a more peaceful world.

Development is a specified state of growth or advancement; a new and advanced product or idea; an event constituting a new stage in a changing situation. All are definitions of development but when we talk about international development more meaning is implied. This briefing explores definitions and perspectives of development and explains how it is different from aid. Development has a history of being linked with capitalism with 'Good Change' commonly associated with industrialization and modernization on the basis of free and fare market policy. Therefore, development is closely bound with ideologies and values. Beliefs about the concept of development shape the assumptions, values, actions, processes and aims of organizations and institutions.

Development is not the same as aid. Aid is the transfer of resources from one place to another. By its nature, it goes into one direction only, often from the north to the south. For instance, when there is a natural disaster or a war, people are in need of immediate basic resources such as food, water and medical care. Aid may be sent in the form of money, equipment, medical staff, food, clothing or similar. However, aid is for immediate relief, but doesn't often contribute to long term rebuilding or recovery. On a smaller scale, money sent by Diasporas to their families' in countries of origin to cover costs of living may be considered aid. Development, on the other hand, is more complex, as explored below. Meaning of 'development' Development is 'Good Change' according to Chambers (1983, 2007), but this is not as straightforward as it sounds. For example, who decides which change is good?

According to Thomas (2000), the word 'development' can be applied into three ways:

Development as Vision: A vision or description of how desirable a society is! The vision of development briefing explores. 
Development as a Historical Process: Social change takes place over long period of time due to inevitable processes. For example, arguments have been made that both capitalism and communism are unavoidable results of progress.

Development as Action: Deliberate effort change things for the better by providing food aid to alleviate hunger.

\section{International Relation and Globalization}

As more nations, people, and cultures adapt to the ever changing international community, diplomats, politicians, and representatives must meet and deal with accordingly to the needs and wants of nations. Diplomacy can be exerted in many forms; through peace talks, written constitutions, and field experiences (Carlsnaes, Thomas Risse, \& Beth A. Simmons, 2013).

Culture is a familiar term and remains unchanged by definition. However, globalization and international relations have constantly altered culture both positively and negatively. Globalization increases worldwide technology, and the readability of fast, effective communication and consumption of popular products. Globalization links cultures and international relations on a variety of levels; economics, politically, socially, etc. International relations have used globalization to reach its goal of understanding cultures. International relations focus on how countries, people and organizations interact; and globalization is making a profound effect on international relations.

Understanding culture, globalization, and international relations is critical for the future of not only governments, people, and businesses, but for the survival of the human race. In today's increasingly interdependent and turbulent world, many of the leading issues in the news concern international affairs. It is the continuing impact of globalization. The process of continuing integration of the countries in the world is strongly underway in all parts of the globe. It is a complex interconnection between capitalism and democracy, which involves positive and negative features that both empowers and overpowers individuals and groups. From the other hand, globalization is a popular term used by governments, business, academic and a range of diverse non-governmental organizations. It also signifies a new 
paradigm within world politics and economic relations. While national governments for many years dictated the international political and economic scene, international organizations such as the World Bank, International Monetary Fund and the World Trade Organization have now become significant role players. In this "Global Village," national governments have lost some of their importance and perhaps, their powers in favour of these major international organizations. As a process of interaction and integration among people, companies and governments of different nations, globalization is a process driven by the international trade and investment and aided by information technology. This process focuses on the environment on culture, on political system, on economic development and prosperity, and on human physical well-being in societies around the world (Sutch \&Juanita, 2007).

\section{International Relation \& Economic Trade and Development}

Capitalist economic theory holds that a completely liberalized global market is the most efficient way to foster growth, because each country specializes in producing the goods and services in which it has a comparative advantage. Yet, in practice, cutting trade barriers and opening markets do not necessarily generate development. Rich countries and large corporations dominate the global marketplace and create very unequal relations of power and information. As a result, trade is, inherently, unequal and poor countries seldom experience rising well-being, but increasing unemployment, poverty, and income inequality (Dixit \& Norman, 1980).

An additional problem is that free trade is not equally free. Agricultural subsidies and other trade barriers in the US and the EU prevent poor countries from gaining access to the most important markets. Meanwhile, poor countries open up their own markets to US and EU exports. Critics of free trade point out that many of the world's richest countries sheltered their economies by protection when they were at the start of their own growth. Further, trade is so dominated by transnational corporations that new trade rules mainly benefit those companies. A number of NGOs have started to promote fair trade, arguing that trade can promote development if it is environmentally sustainable and includes respect for 
human and labor rights. This paper provides information on trade issues, including how to make trade contribute to development. The trade and development of a country largely depends on international relation, especially structural changes. Economic structural change refers to a long-term shift in the fundamental structure of an economy, which is often linked to growth and economic development. For example, a subsistence (prevalent) economy may be transformed into a manufacturing economy, or a regulated mixed economy is liberalized. A current driver of structural change in the world economy is globalization. Structural change is possible because of the dynamic nature of the economic system (Milner, 1997).

Patterns and changes in sector employment drive demand shifts through the income elasticity. Shifting demand for both locally sourced goods and for imported products is a fundamental part of development. The structural changes that move countries through the development process are often viewed in terms of shifts from primary, to secondary and finally, to tertiary production. Technical progress is seen as crucial in the process of structural change as it involves the obsolescence (obsolete) of skills, vocations, and permanent changes in spending and production resulting in structural unemployment. Moreover, structural changes of a country include culvert, bridges, gas, electricity, road communication, education, mills \& factories, manpower, garments, school, college, university, export \& import, economy, trade \& commerce, transportation, industrialization, urbanization, science \& technology, games \& sports, credit and so on.

For structural changes, a developing country like Bangladesh has to depend on foreign aid. When she is unable to meet the investment for her structural changes, then international relation is a must. For international relation, a country has to relay on the help of World Bank, Asian Development Bank, World Trade Organization and so on.

Export \& import of a country depends on international relation. For this, she needs help from World Trade Organization. Due to IR, a country takes credit (loan) from any foreign country. Ideas, cultural trends like food, clothing, manner, and so on are dealt with IR. People can share their views \& opinions with another country, and they can establish international brotherhood, and friendship, then, it becomes possible for them due to IR. 
There is a need for a strategic approach to export opportunities arising from trade preference, viewing them not as a basis for long term strategy, but rather as a stepping stone. Moreover, structural transformation is dependent on international trade rules, particularly to facilitate the development of new economy activities and non-traditional export. This can be done through international relation. International relational plays a significant role in engineering sectors including EEE, CSE, CE, IT and so on. Engineers can participate in international conference, seminar, and symposium to acquire engineering knowledge, thus they can be able to develop a country economically. Due to IR, a country can take loan from any foreign country when she falls in economic constraints, and she cannot be able to meet the minimum necessity of her people.

Poverty alleviation of a country may be lessened immediately if she enables to maintain IR with the developed countries of the universe. As we know, ours is a poverty affected country. In this regards, IR functions importantly. The prosperity of a country largely relies on garments sector, many poor and common people work on garments factory, and they lead their livelihood based on these working places. So a country must be trying to keep a good international relation with the capitalist countries. Again, when any country falls in natural calamity like flood, storm, and diseases, IR plays an important role in this regards. Medical science also depends upon IR. A developing country like Bangladesh has a poor medical science system, the doctors are not well trained up, they urgently need foreign course and how to behave and treat with the patients. But doctors of our country are selffish \& money minded. They do not try to do research course on medical science, they should participate in international seminar, symposium and conference. Thus a country has to cope with IR for her development.

Global English is a must in this regards, Since English has achieved the prestige of international recognition. So, people have to acquire the basic knowledge of English. Thus, a nation of a country may keep international relation. Scholarship of meritorious students is available around the universe. But a developing country like Bangladesh lags behind, and most of the students cannot get scholarship around the developed world. But the govt. should inspire them to get scholarship, and at the same time he ought to offer proper opportunities for them. This can be done through copying with international relation with 
the foreign countries. Without maintaining international relation, a country has to face economic crises and hurdles. As a result, she fails to receive foreign aid.

\section{The Significance of the Study}

A country cannot develop without international relations. Its trade, development and economy largely depend on international relations. This paper signifies that international relations should be developed to bring about significance change in the field of trade and development. Moreover, if we want to live in the post-modern era, there is no any alternative means without international relations. Through the process of international relations, a developing country like Bangladesh may go a long way. Therefore, to spread trade and development in any country, the conscious people should come forward to upgrading international relations.

\section{Conclusion and Recommendations}

Finally, we can assume that this study is based on international relation, trade, development, international relation and globalization, international relation, economic trade and development.

The government and conscious citizens should take immediate steps to extend international relation around the universe. He should maintain good relation with the foreign country. And, at the same time the government ought to make massive awareness throughout the country with a view to extending trade \& development with the globalizing process. Consequently, a country like Bangladesh can be able to develop her economic potential and trade if she takes proper steps.

\section{References}

Arndt, H. W. (1987). Economic Development: The History of an Idea. Chicago: University of Chicago Press.

Carlsnaes, Walter, Thomas Risse, \& Beth A. Simmons.eds. (2013). “Handbook of International Relations," London: SAGE Publication Ltd. 
Chambers, R. (1983). Rural Development: Putting the First Last. London: ITDG.

Chambers, R. (2004). Ideas for Development. IDS Working Paper 238. Sussex: IDS.

Dixit, A. \& V. Norman. (1980). Theory of International Trade: A Dual General Equilibrium Approach Cambridge: Cambridge University Press. Saylor URL: http://www.saylor.org/books

Emeka, E.J., Frederick, I. \& Peter, A. (2012). "Macroeconomic Impact of Trade on Nigerian Growth: An Empirical Evaluation", in Research Journal of Business Management and Accounting. Vol. 1(4), 079-083

Griffiths, Martin, and Terry O'Callaghan. (2002). International Relations: The Key Concepts. London \& New York: Routledge. pp.75-77

Hausmann, R. and Rodrik, D. (2003). "Economic Development as Self-discovery," in Journal of Development Economic. Vol-72, No-2,pp.603-633.

Head, K. and Ries, J.(2006). “Do Trade Missions Increase Trade?, in Working Paper Series.

Johnson, H. G. (1967). International Trade and Economic Growth. Cambridge, Mass.

Lewis, W. A. (1954). "Economic Development with Unlimited Supplies of Labour", in Mancherster School of Economic and Social Studies. 22, May, pp. 139-191.

Li, Y., Chen, Z. \& San, C. (2010). "Research on the Relationship between Foreign Trade and the GDP Growth of East China- Empirical Analysis Based on Causality", in Modern Economy, $1,118-124$

Milner, HV. (1997). Interests, Institutions, and Information: Domestic Politics and International Relations. Princeton: Princeton University Press.

Sen, Sunanda. (November 2005). "International Trade Theory \& Policy: What Is Left of the Free Trade Paradigm?" Development and Change 36(6): 1011-29, New York: Levy Economics Institute. 
Sun, Peng. (August 2010). "International Trade and its Effects on Economic Growth in China," in Liaoning Entry-Exit Inspection and Quarantine Bureau (LNCIQ), Almas Heshmati Korea University and IZA.

Sutch, Peter \&Juanita Elias. (2007). International Relations the Basics. London \& New York: Tailor \& Francis Group.

Thomas, A. (2004). The Study of Development. Paper prepared for DSA Annual Conference, 6 November, Church House, London. 